\title{
Cyclosporin A, but not tacrolimus, negatively affects the hepatic extraction fraction of hepatobiliary scintigraphy in liver transplant recipients
}

\author{
Anastasios Kaxiras ${ }^{1}$, Shinji Yamamoto ${ }^{1 *}$, Gunnar Söderdahl', Annika Wernerson², Rimma Axelsson ${ }^{3}$ \\ and Bo-Göran Ericzon ${ }^{1}$
}

\begin{abstract}
Background: Hepatobiliary scintigraphy using ${ }^{99 m} \mathrm{Tc}$-mebrofenin has been used as an investigation to study liver function after liver transplantation (LTX). Hepatic extraction fraction (HEF) is a measurement of the hepatic extraction efficiency and hepatic extraction rate. With the purpose of evaluating a possible diverging effect of cyclosporin A (CSA) and tacrolimus (TAC) on the HEF, we compared the HEF with biochemical and histological parameters in LTx patients receiving either CSA or TAC.
\end{abstract}

Methods: Thirty-nine adult patients who underwent LTx due to hepatitis C virus (HCV) cirrhosis were evaluated. All patients underwent a 3-month and 1-year follow-up that included hepatobiliary scintigraphy and biochemistry tests. Liver biopsy was performed at 1 year. These clinical parameters were compared between the two groups, TAC $(n=15)$ and CSA $(n=24)$.

Results: The average HEF was significantly lower in the CSA group compared to the TAC group both at 3 months and 1 year after LTX. The liver biochemistry tests, average donor and recipient age, average cold ischemia time (CIT), and a clearance were comparable in the two groups. The TAC group had more inflammation than the CSA group. Moreover, three patients who converted from CSA to TAC increased their HEF values.

Conclusions: CSA-treated patients presented a lower HEF value on hepatobiliary scintigraphy in spite of comparable liver function by traditional measurements indicating a decrease on HEF values by CSA.

Keywords: Hepatobiliary scintigraphy; Hepatic extraction rate; Liver transplantation; Cyclosporin A; Tacrolimus; Hepatitis C

\section{Background}

Liver transplantation (LTx) is an established treatment for patients with end-stage liver disease, and LTx has been performed in Sweden since 1984 [1]. Liver cirrhosis caused by hepatitis $\mathrm{C}$ virus (HCV) is a common indication for LTx [2]. Approximately one-fifth of transplant recipients at our institute had liver cirrhosis caused by $\mathrm{HCV}$ [3]. Recurrence of $\mathrm{HCV}$ infection can occur as early as 4 weeks after liver transplantation [4]; this may

\footnotetext{
* Correspondence: shinjiyamamoto2000@hotmail.com

'Division of Transplantation Surgery and CLINTEC, Karolinska University

Hospital, Huddinge, and Karolinska Institutet, Stockholm, Sweden Full list of author information is available at the end of the article
}

develop into severe hepatitis requiring anti-viral treatment within the first 6 months after LTx [5-7]. The recurrence of $\mathrm{HCV}$ infection is usually diagnosed by blood biochemistry tests, HCV-RNA test, and liver graft biopsy. Other methods are also used for follow-up and to evaluate liver graft function after LTx. These include radiological examinations, transient elastography (fibroscan), and hepatobiliary scintigraphy. Hepatobiliary scintigraphy has emerged as one of the valuable methods to assess graft function [8-14]. The most common agent used for nuclear imaging with scintigraphy worldwide and by us is ${ }^{99 \mathrm{~m}} \mathrm{Tc}$-mebrofenin (2,4,6-trimethyl-3 bromo iminodiacetic acid) [14-16]. Hepatobiliary scintigraphy is 
a noninvasive method and allows for detection of postoperative structural complications such as biliary obstructions/dilatations and biliary leakage. In addition, it can provide information concerning functional components of the liver graft, such as the rate of uptake, perfusion, and excretion of a tracer [9]. One important parameter of biliary scintigraphy that is of great value in the evaluation of transplanted liver grafts is the hepatic extraction fraction (HEF) [14]. HEF is a measurement of the hepatic extraction efficiency and hepatic extraction rate [14-16]. We have previously reported a significant correlation between early post-LTx HEF values and biochemical parameters [14].

A high level of serum bilirubin in the blood is known to interact with the uptake and/or excretion of scintigraphic agents in the liver, thereby affecting the scintigraphy results [14]. A previous study performed in an animal model showed that cyclosporin A (CSA) possibly impaired the ${ }^{99 \mathrm{~m}} \mathrm{Tc}$-mebrofenin excretion [17]. It might indicate that CSA affects the rate of HEF negatively. However, this negative effect has not been proved in scintigraphy with humans so far. In this retrospective study, we analyzed the results of hepatobiliary scintigraphy performed at the 3month and 1-year post-transplantation check-up in patients transplanted as a result of $\mathrm{HCV}$ cirrhosis. We then compared the scintigraphic results to the traditional biochemical and histological parameters between the two groups of patients, receiving either CSA or tacrolimus (TAC) with the purpose of evaluating a possible diverging effect of these drugs on the HEF.

\section{Methods}

\section{Patients}

Thirty-nine adult patients who underwent LTx due to a single indication, i.e., HCV cirrhosis at the Karolinska University Hospital between March 2007 and May 2011, were included in the study. During this time period, our center performed routine hepatobiliary scintigraphy at 3 and 12 months after LTx. Thirty-eight patients received a whole-liver graft $(n=38)$ and one received a right lobe graft from a deceased donor. The patients were divided into two groups, those that received TAC from the first day after transplantation (TAC group, $n=15$ ) and those that received CSA (CSA group, $n=24$ ). Several clinical parameters at the time of transplantation were also analyzed, including donor and recipient age, recipient gender, malignancy and the cold ischemia time (CIT). Characteristics of the patients in both groups are shown in Table 1. The study was approved by the review board of the ethical committee at Karolinska Institutet, Sweden.

\section{Immunosuppression}

During the study period, the selection of CSA or TAC in patients with $\mathrm{HCV}$ cirrhosis was based on the operating surgeons' own choice and no special criteria were used (CSA; $n=14$, TAC; $n=15$ ). However, after November 2010, only CSA was used in these patients (CSA; $n=10)$. All patients in the TAC group received a double-regime immunosuppression protocol without induction therapy, i.e., TAC + cortisone. The patients in the CSA group received a triple immunosuppression regime without induction therapy, i.e., CSA + Azathioprine (AZA) + cortisone. The initial dose was $0.1 \mathrm{mg} / \mathrm{kg} /$ day for the TAC group and $10 \mathrm{mg} / \mathrm{kg} /$ day for the CSA group, both divided in two doses a day. The target trough level in the first three postoperative months was 8 to $10 \mathrm{ng} / \mathrm{ml}$ for the TAC group and 200 to $300 \mathrm{ng} / \mathrm{ml}$ for the CSA group. Beyond the 3 months, the target level was reduced to 4 to $6 \mathrm{ng} / \mathrm{ml}$ for the TAC group and 150 to $200 \mathrm{ng} / \mathrm{ml}$ for the CSA group. In the CSA group, CSA was converted to TAC treatment in three patients before the 1-year follow-up scintigraphy was performed. In the TAC group, TAC was converted to everolimus in one patient at the time of the 1-year followup. According to our protocol, the initial dosage of AZA was $3 \mathrm{mg} / \mathrm{kg}$ at a maximum dose of $150 \mathrm{mg} /$ day, reduced to 1 to $2 \mathrm{mg} / \mathrm{kg}$ after the 3-month follow-up and subsequently withdrawn after the 1-year follow-up. However, nine patients in the CSA group had the AZA removed earlier than 1 year after LTx because of side effects, mainly anemia and/or leucopenia. The time of drug removal

Table 1 Characteristics of $39 \mathrm{HCV}$ positive patients who underwent LTx

\begin{tabular}{|c|c|c|c|c|}
\hline & Total $(n=39)$ & $\begin{array}{l}\text { Cyclosporine A } \\
(n=24)\end{array}$ & $\begin{array}{l}\text { Tacrolimus } \\
(n=15)\end{array}$ & $p$ value \\
\hline \multirow[t]{2}{*}{ Recipient age (years) (range, average \pm S.D.) } & 42 to 67 & 43 to 67 & 42 to 66 & 0.62 \\
\hline & $56.1 \pm 6.6$ & $55.7 \pm 6.8$ & $56.8 \pm 6.3$ & \\
\hline Gender (male/female) & $25 / 14$ & $14 / 10$ & $11 / 4$ & 0.90 \\
\hline HCC (\%) & $17(43.6 \%)$ & $12(50 \%)$ & $5(33.3 \%)$ & 0.31 \\
\hline Donor age (years) (range, average \pm SD) & 16 to $74(54.5 \pm 13.8)$ & 16 to $74(53.3 \pm 17.0)$ & 43 to $64(56.3 \pm 6.4)$ & \\
\hline Cold ischemic time (minutes, range, average $\pm \mathrm{SD}$ ) & 240 to $775(501.3 \pm 121.9)$ & 350 to $751(513.3 \pm 111.9)$ & 240 to $775(482.1 \pm 138.3)$ & \\
\hline $\begin{array}{l}\text { Post-operative complication with bile duct } \\
\text { stricture/bile leakage }\end{array}$ & $4(10.3 \%)$ & $3(12.5 \%)$ & $1(6.7 \%)$ & 0.56 \\
\hline
\end{tabular}

LTx, liver transplantation; SD, standard deviation; HCC, hepatocellular carcinoma. 
varied from 2 weeks to 9 months after LTx (median, 3.0 months).

\section{Follow-up of the patients}

All patients underwent a 3-month follow-up that included hepatobiliary scintigraphy and blood biochemistry tests: s-bilirubin, alanine aminotransferase (ALAT), aspartate aminotransferase (ASAT), alkaline phosphatase (ALP), and gamma-glutamyl transpeptidase (GT). Hepatobiliary scintigraphy and the same blood biochemistry tests were repeated at the 1-year follow-up; in addition creatinine and iohexol clearance and a liver biopsy were performed at 1 year.

\section{Hepatobiliary scintigraphy}

\section{Procedure}

Hepatobiliary scintigraphy was performed on a large field-of-view gamma camera (Diacam; Siemens, Munich, Germany) at 3 months and 12 months post-operatively. A dynamic acquisition was started directly after a bolus injection of $200 \mathrm{MBq}{ }^{99 \mathrm{~m}} \mathrm{Tc}$ mebrofenin, which is rapidly taken up by hepatocytes from circulating blood and extracted into the biliary tract without conjugation (Figure 1a,b). Data were acquired at a rate of one frame per $10 \mathrm{~s}$ over $30 \mathrm{~min}$ using a $256 \times 256$ matrix. The field of view included the heart, the liver, and the upper abdomen. A 5-min anterior view was acquired $1 \mathrm{~h}$ after injection.

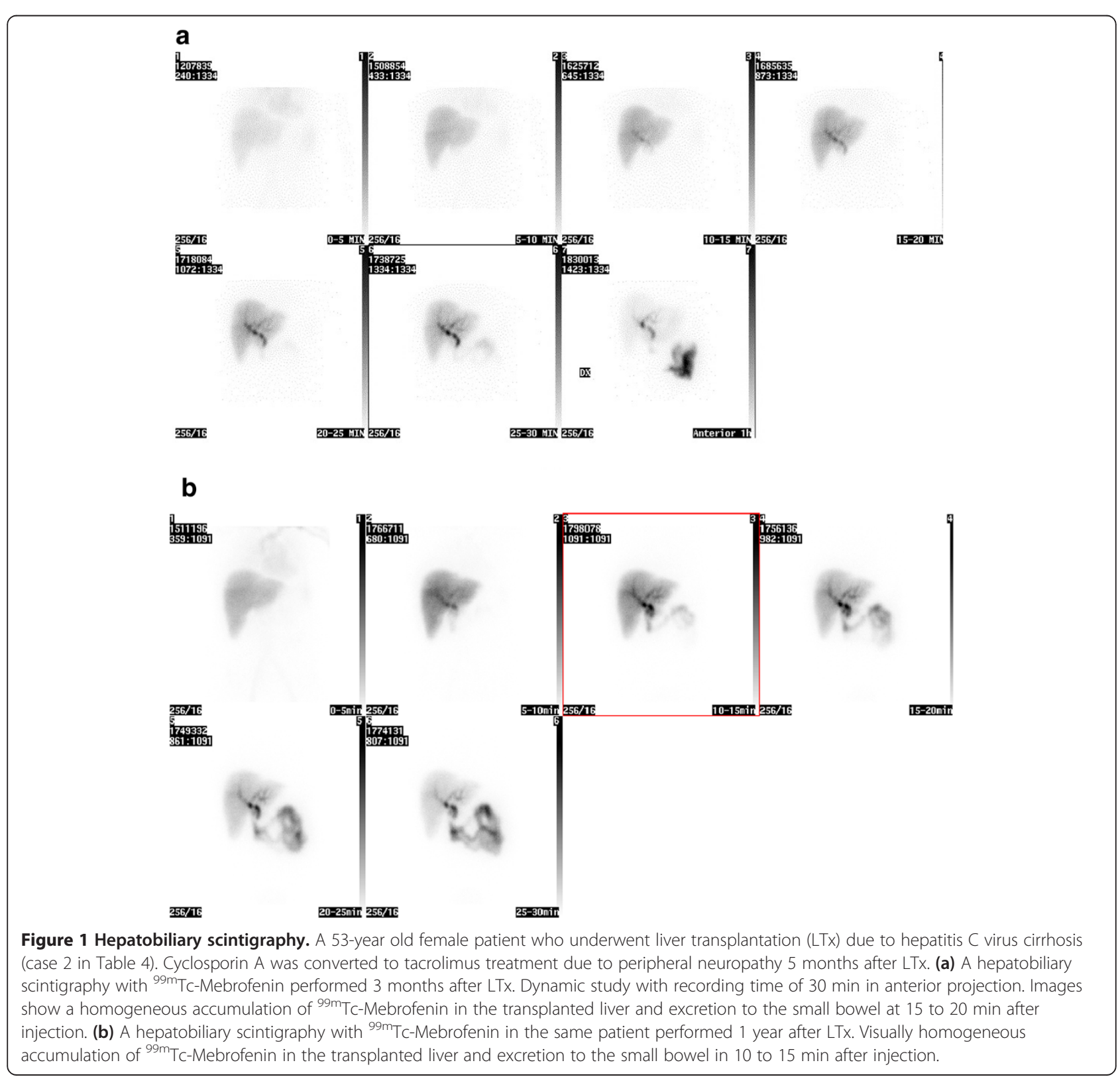




\section{Evaluation}

The HEF was calculated using a restricted matrix algorithm deconvolution technique [17]. A region of interest (ROI) was drawn over the left ventricle of the heart, excluding the aorta and scatter from the liver. A second ROI was drawn over the entire liver parenchyma, excluding the main bile duct from the ROI in order to eliminate the risk of overlapping of excreted radioactivity from bile duct and the true radioactivity of the liver parenchyma (gallbladder was removed from the liver graft during operation).

Time-activity curves were generated from these regions, and the heart curve was used as the input function in the deconvolution analysis. The deconvoluted liver curve thus represents a hypothetical true liver response following a direct bolus injection into the hepatic artery. An exponential curve was fitted by the leastsquares method to the deconvoluted liver curve. The intercept of the fitted curve is proportional to the hepatocyte function, while the maximum of the deconvoluted liver curve represents the total input to the liver. HEF is calculated as: $\mathrm{HEF}=$ intercept exponential-fit liver response curve/max. data value liver response curve (Figure 2a,b).

\section{Liver biopsies}

All liver biopsies were performed under the guidance of ultrasound, and all were analyzed by one experienced pathologist. The findings recorded were inflammation, fibrosis, steatosis, and the histological evidence of $\mathrm{HCV}$ recurrence. The grading system for the evaluation of the degree of inflammation/fibrosis/steatosis is as follows: 0: none, 1: light, 2: moderate, and 3: severe. HCV recurrence was diagnosed by the presence of focally intense lymphocytic infiltrates in portal areas, focal infiltration of a single interlobular bile duct without duct loss, a variable degree of piecemeal necrosis, and the absence of severe portal/hepatic venular endotheliitis [5].

\section{Statistical analysis}

The STATISTICA statistical program (Statsoft inc., Tulsa, OK, USA) was used for the statistical analysis in this study. The chi-square test was performed for categorical variables and Student $t$ test was performed for continuous variables. A $p$ values $<0.05$ was considered as statistically significant.

\section{Results}

\section{Characteristics of CSA and TAC groups}

In Table 1, the characteristics of both patient groups are shown. There was no statistical difference of recipient, donor and graft parameters, and post-operative complication between the CSA group and the TAC group. Three patients in the CSA group and two patients in the
TAC group received intravenous bolus steroid therapy for biopsy-verified acute rejection within 3 months after LTx. There was no statistical difference of the occurrence of acute rejection between the two groups.

\section{Scintigraphic and biochemical parameters at a 3-month follow-up}

The time intervals between LTx and 3-month follow-up hepatobiliary scintigraphy were 2.7 to $3.5,3.1 \pm 0.2$ months (range, average \pm standard deviation $(\mathrm{SD})$ ). There was a significant difference of the average of HEF values at the 3-month hepatobiliary scintigraphy; 11 to $90,35.8 \pm 21.2 \%$ (range, average \pm S.D.) in the CSA group and 46 to 100 , $87.3 \pm 14.8 \%$ in the TAC group $(p<0.0001)$. Average of serum bilirubin was normal in both groups but significantly higher in the CSA group. There was a significant difference in the value of bilirubin between the two groups, $(18.1 \pm 13.5$ vs $8.9 \pm 8.4 \mu \mathrm{mol} / \mathrm{l}$, respectively; $p=$ 0.02). ALAT, ASAT, ALP, and GT were similar between the two groups (Table 2).

\section{Scintigraphic and biochemical parameters 1-year after LTx}

The time intervals between LTx and 1-year follow-up hepatobiliary scintigraphy were 11.4 to $12.9,12.1 \pm$ 0.4 months (range, average $\pm \mathrm{SD}$ ). The average of HEF in the CSA group was significantly lower at 1 year after LTx than in patients treated with TAC (17 to 79, $44.7 \pm$ $18.4 \%$ vs 37 to $100,85.2 \pm 23.6 \%$ (range, average \pm SD); $p<0001)$. The average HEF in CSA treated patients who were on treatment with AZA at 1 year was $44.9 \pm 19.4$ compared to $53.3 \pm 28.0$ in patients who discontinued AZA $(p=0.39)$. There was no statistical difference in the liver and renal function by blood biochemistry evaluation between the CSA and TAC groups (Table 3).

\section{HEF of patients who converted from CSA to TAC}

Table 4 shows the HEF and serum bilirubin values at 3 months and 1 year after LTx in three patients who converted from CSA to TAC. Conversion was done between 3.7 to 6.3 months post-operatively. One patient (case 1) had normal bilirubin at the time of the two follow-ups and HEF increased from $27 \%$ to $90 \%$. The second patient (case 2) who had slightly increased bilirubin at 3 months but a normal value at 1 year had HEF increased from $42 \%$ to $100 \%$ after conversion. Hepatobiliary scintigraphy and HEF of this case 3 months and 1 year after LTx are shown in Figures 1 and 2. The third patient (case 3) who had post-operative complication with bile duct stricture increased HEF from $13 \%$ to $26 \%$ in spite of a significant increase in serum bilirubin from 41 to $142 \mu \mathrm{mol} / \mathrm{l}$.

\section{HEF inpatients with post-surgical complications}

Post-surgical complications were evaluated in the patients. No re-operation was performed during the follow-up 

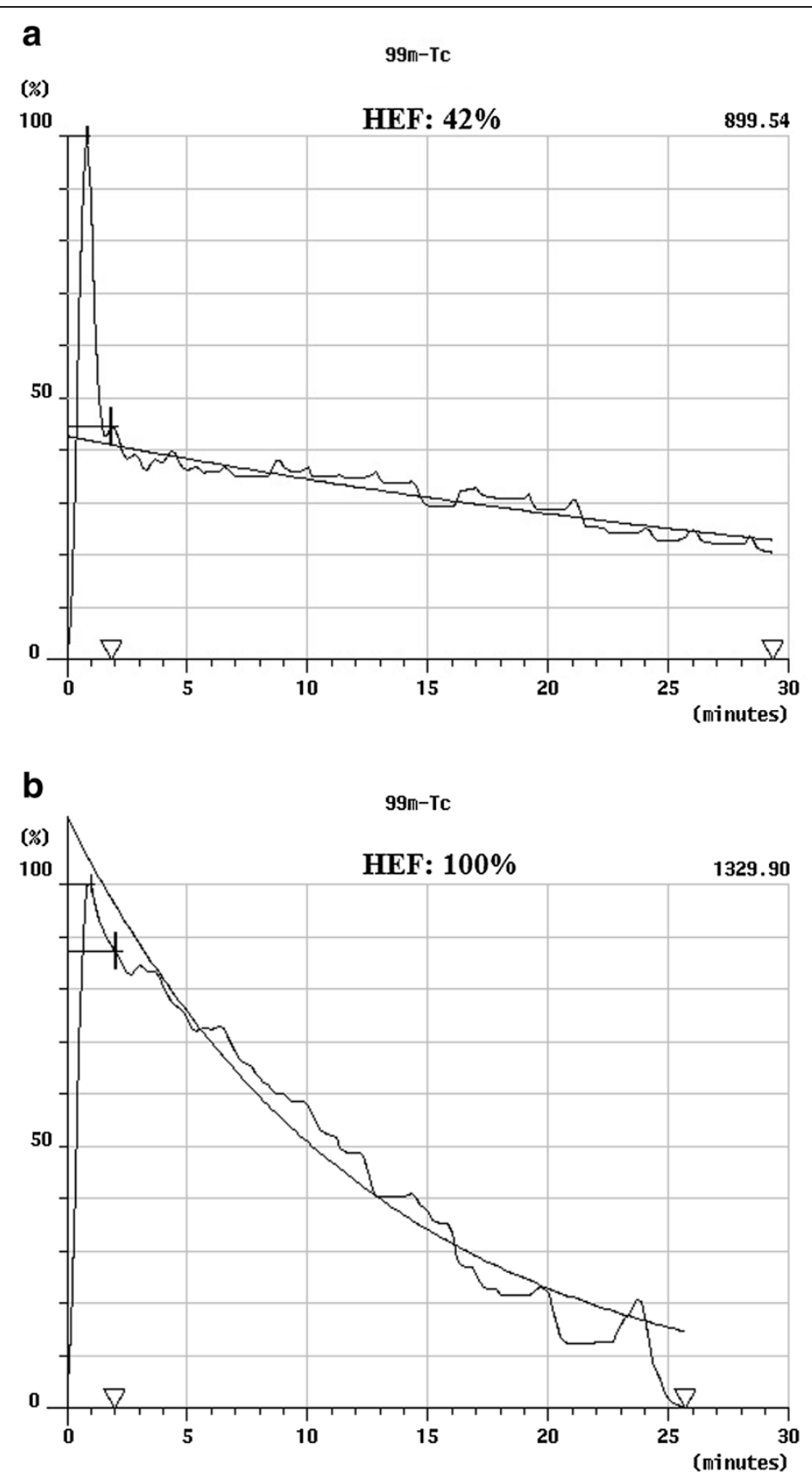

Figure 2 Hepatic extraction fraction. A 53-year old female patient who underwent liver transplantation (LTx) due to hepatitis C virus cirrhosis (case 2 in Table 4). Cyclosporin A was converted to tacrolimus treatment due to peripheral neuropathy 5 months after LTx. (a) Calculation of hepatic extraction fraction (HEF) in the same patient at 3 months imaging. HEF is calculated by the ratio of the initial hepatocyte uptake divided by the peak vascular uptake (42\%). (b) Calculation of HEF in the same patient 1 year after LTX. HEF increased from 42\% to 100\%.

period. Four patients (2 in CSA group, 1 in TAC group and 1 in CSA converted to TAC at 6.3 months after LTx) presented with bile duct stricture $(n=3)$ and bile leakage $(n=1)$. Bile duct stricture and leakage was treated by dilatation of the stricture and bile duct stent placement with endoscopic retrograde cholangiopancreatography (ERCP) and percutaneous transhepatic cholangio drainage (PTCD). Table 5 shows the HEF and serum bilirubin values in these patients. Case 1 in the CSA group had normalized bilirubin value at 1 year; however, the HEF decreased from $46 \%$ to $37 \%$. Case 2 in the TAC group had bile duct complications with high bilirubin values at both 3 months and 1 year after LTx even after the intervention and had low HEF values; $14 \%$ and $17 \%$, respectively. Case 4 in the CSA group, who had complication of bile leakage after the removal of the T-tube at 1 month after LTx, had 
Table 2 Results of scintigraphic and biochemical parameters in CSA and TAC groups at 3-month control

\begin{tabular}{|c|c|c|c|c|}
\hline $\begin{array}{l}\text { Parameters } \\
\text { (range, } \\
\text { average } \pm \text { SD) }\end{array}$ & $\begin{array}{l}\text { Total } \\
(n=39)\end{array}$ & $\begin{array}{l}\text { CSA at } 3 \\
\text { months } \\
(n=24)\end{array}$ & $\begin{array}{l}\text { TAC at } 3 \\
\text { months } \\
(n=15)\end{array}$ & $p$ value \\
\hline \multirow[t]{2}{*}{ HEF (\%) } & 11 to 100 & 11 to 90 & 46 to 100 & $<0.0001$ \\
\hline & $55.6 \pm 31.6$ & $35.8 \pm 21.2$ & $87.3 \pm 14.8$ & \\
\hline Bilirubin $(\mu \mathrm{mol} / \mathrm{l})$ & 2.0 to 59.0 & 5.0 to 59.0 & 2.0 to 38.0 & 0.02 \\
\hline Ref: $<26$ & $14.6 \pm 12.6$ & $18.1 \pm 13.5$ & $8.9 \pm 8.4$ & \\
\hline ALAT ( $\mu k a t / I)$ & 0.1 to 1.6 & 0.1 to 1.6 & 0.2 to 1.0 & 0.57 \\
\hline Ref: $<0.76$ & $0.6 \pm 0.3$ & $0.6 \pm 0.4$ & $0.5 \pm 0.2$ & \\
\hline ASAT ( $\mu k a t / l)$ & 0.2 to 2.5 & 0.2 to 2.5 & 0.2 to 1.2 & 0.33 \\
\hline Ref: $<0.61$ & $0.6 \pm 0.4$ & $0.7 \pm 0.5$ & $0.5 \pm 0.2$ & \\
\hline ALP ( $\mu \mathrm{kat} / \mathrm{I})$ & 0.8 to 18.1 & 0.8 to 5.8 & 0.8 to 18.1 & 0.16 \\
\hline Ref: $<1.9$ & $2.1 \pm 2.9$ & $1.6 \pm 1.2$ & $3.0 \pm 4.4$ & \\
\hline GT ( $\mu$ kat/l) & 0.3 to 22.7 & 0.3 to 8.8 & 0.4 to 22.7 & 0.16 \\
\hline Ref: $<1.3$ & $2.8 \pm 4.6$ & $2.0 \pm 2.3$ & $4.1 \pm 6.7$ & \\
\hline
\end{tabular}

CSA, cyclosporine A; TAC, tacrolimus; ALAT, alanine aminotransferase; ASAT aspartate aminotransferase; ALP, alkaline phosphatase; GT, gamma-glutamyl transpeptidase.

normal bilirubin values at 3 months and 1 year after LTx; however, the HEF values were low; $29 \%$ and $41 \%$, respectively.

\section{Liver biopsy at the 1-year follow-up}

The results of the liver biopsy taken 1 year after LTx are shown in Table 6. There was no significant difference in

Table 3 Results of scintigraphic and biochemical parameters in CSA and TAC groups at 1-year control

\begin{tabular}{|c|c|c|c|c|}
\hline $\begin{array}{l}\text { Parameters } \\
\text { (range, } \\
\text { average } \pm \text { SD) }\end{array}$ & $\begin{array}{l}\text { Total } \\
(n=38)\end{array}$ & $\begin{array}{l}\text { CSA at } \\
1 \text { year } \\
(n=21)\end{array}$ & $\begin{array}{l}\text { TAC at } \\
1 \text { year } \\
(n=17)\end{array}$ & $p$ value \\
\hline \multirow[t]{2}{*}{ HEF (\%) } & 17 to 100 & 17 to 79 & 37 to 100 & $<0.0001$ \\
\hline & $62.8 \pm 29.0$ & $44.7 \pm 18.4$ & $85.2 \pm 23.6$ & \\
\hline \multirow[t]{2}{*}{ Bilirubin $(\mu \mathrm{mol} / \mathrm{l})$} & 3.0 to 146.0 & 4.0 to 146.0 & 3.0 to 142.0 & 0.88 \\
\hline & $18.5 \pm 30.4$ & $17.8 \pm 29.9$ & $19.4 \pm 32.0$ & \\
\hline \multirow[t]{2}{*}{ ALAT ( $\mu \mathrm{kat} / \mathrm{l})$} & 0.2 to 3.9 & 0.2 to 3.0 & 0.2 to 3.9 & 0.13 \\
\hline & $1.1 \pm 1.0$ & $0.8 \pm 0.7$ & $1.3 \pm 1.2$ & \\
\hline \multirow[t]{2}{*}{ ASAT ( $\mu$ kat/l) } & 0.3 to 3.0 & 0.3 to 2.4 & 0.3 to 3.0 & 0.38 \\
\hline & $0.9 \pm 0.7$ & $0.8 \pm 0.5$ & $1.0 \pm 0.9$ & \\
\hline \multirow[t]{2}{*}{ ALP ( $\mu$ kat/l) } & 0.7 to 5.8 & 0.7 to 5.8 & 0.8 to 4.8 & 0.44 \\
\hline & $1.8 \pm 1.0$ & $1.9 \pm 1.4$ & $1.7 \pm 1.0$ & \\
\hline \multirow[t]{2}{*}{ GT ( $\mu$ kat/l) } & 0.2 to 26.2 & 0.4 to 8.1 & 0.2 to 26.2 & 0.12 \\
\hline & $3.2 \pm 5.1$ & $2.1 \pm 2.3$ & $4.6 \pm 7.0$ & \\
\hline \multirow[t]{2}{*}{ Creatinine, $(\mu \mathrm{mol} / \mathrm{l})$} & 60.0 to 273.0 & 60 to 273.0 & 63 to 177.0 & 0.23 \\
\hline & $117.1 \pm 44.6$ & $124.9 \pm 53.6$ & $107.5 \pm 28.7$ & \\
\hline \multirow{2}{*}{$\begin{array}{l}\text { lohexol clearance, } \\
\left(\mathrm{ml} / \mathrm{min} / 1.7 \mathrm{~m}^{2}\right)\end{array}$} & 6.4 to 91.0 & 18.0 to 78.0 & 6.4 to 91 & 0.33 \\
\hline & $51.3 \pm 17.4$ & $48.8 \pm 16.0$ & $54.4 \pm 19.0$ & \\
\hline
\end{tabular}

Table 4 Results of scintigraphic parameters in patients who converted from CSA to TAC at 1-year control

\begin{tabular}{|c|c|c|c|}
\hline & Case 1 & Case 2 & Case 3 \\
\hline $\begin{array}{l}\text { Time of converting } \\
\text { after LTx }\end{array}$ & 3.7 months & 5.0 months & 6.3 months \\
\hline Reason for converting & $\begin{array}{l}\text { Side effect } \\
\text { (hair growth) }\end{array}$ & $\begin{array}{l}\text { Side effect } \\
\text { (peripheral } \\
\text { neuropathy) }\end{array}$ & $\begin{array}{l}\text { Side effect } \\
\text { (altered } \\
\text { mental status) }\end{array}$ \\
\hline 3-month HEF (\%) & 27 & 42 & 13 \\
\hline $\begin{array}{l}\text { Bilirubin, 3-month } \\
\text { follow-up }(\mu \mathrm{mol} / \mathrm{l})\end{array}$ & 13 & 29 & 41 \\
\hline 1-year HEF (\%) & 90 & 100 & 26 \\
\hline $\begin{array}{l}\text { Bilirubin, 1-year } \\
\text { follow-up }(\mu \mathrm{mol} / \mathrm{l})\end{array}$ & 10 & 8 & 142 \\
\hline
\end{tabular}

degrees of fibrosis and steatosis between the CSA and TAC groups; however, there was a significantly higher degree of inflammation in the TAC group compared to the CSA group $(p=0.005)$. The rate of the histopathologically confirmed recurrence of hepatitis $C$ was $57.1 \%$ $(12 / 21)$ in the CSA group and $50.0 \%(7 / 14)$ in the TAC group $(p=0.68)$.

\section{Discussion}

The monitoring of graft function after LTx is a complex procedure. Evaluation of graft function commonly consists of liver blood biochemistry tests, liver biopsy, transient elastography, and hepatobiliary scintigraphy. Liver transplant patients receive either CSA or TAC as the main immunosuppressant. CSA has been shown to exert some anti-HCV properties in vitro [18] and is still frequently used in these patients. One animal study showed a negative effect of CSA on the excretion of the tracer ${ }^{99 \mathrm{~m}}$ Tc-mebrofenin, thus possibly confusing the evaluation of liver function when comparing patients treated with CSA or TAC. The aim of this study was to evaluate whether CSA impaired the result of hepatobiliary scintigraphy using ${ }^{99 \mathrm{~m}} \mathrm{Tc}-\mathrm{mebrofenin}$ or not. For that purpose, the results of HEF at 3 months and 1 year after LTx were compared between the CSA and TAC groups.

In recent years, CSA has not been used as the initial immunosuppressive drug at our institute, with the exception of $\mathrm{HCV}$ positive patients. To eliminate the recipients' factor of primary disease that might affect graft function, only patients who underwent LTx due to $\mathrm{HCV}$ cirrhosis were evaluated in this study.

There was no difference in recipient and donor age, recipient gender, malignancy rate, and CIT between the CSA and TAC groups, which indicates that there is no significant pre-LTx bias in the two patient groups. Neither was there any difference in the occurrence of acute rejection, which indicates that there was no significant difference of the immunosuppressive potency between the two groups. 
Table 5 Results of scintigraphic parameters in patients who had bile duct complications

\begin{tabular}{|c|c|c|c|c|}
\hline $\begin{array}{l}\text { Case and } \\
\text { immunosuppression }\end{array}$ & Case 1 CSA & Case 2 TAC & Case 3 CSA to TAC & Case 4 CSA \\
\hline $\begin{array}{l}\text { Complications, time of the } \\
\text { onset of treatment after LTx }\end{array}$ & Bile duct stricture, 4 months & Bile duct stricture, 1.5 months & $\begin{array}{l}\text { Bile duct stricture, } \\
5 \text { months }\end{array}$ & $\begin{array}{l}\text { Bile leakage after the } \\
\text { removal of T-tube, } \\
1 \text { month }\end{array}$ \\
\hline Treatment & $\begin{array}{l}\text { Dilatation and bile duct stent } \\
\text { placement by ERCP, PTCD }\end{array}$ & $\begin{array}{l}\text { Dilatation and bile duct stent } \\
\text { placement by ERCP, PTCD }\end{array}$ & $\begin{array}{l}\text { Dilatation and bile duct } \\
\text { stent placement by ERCP }\end{array}$ & $\begin{array}{l}\text { Bile duct stent placement } \\
\text { by ERCP, PTCD }\end{array}$ \\
\hline 3-month HEF (\%) & 46 & 14 & 13 & 29 \\
\hline $\begin{array}{l}\text { Bilirubin, 3-month follow-up } \\
(\mu \mathrm{mol} / \mathrm{l})\end{array}$ & 38 & 59 & 41 & 16 \\
\hline 1-year HEF (\%) & 37 & 17 & 26 & 41 \\
\hline $\begin{array}{l}\text { Bilirubin, 1-year follow-up } \\
(\mu \mathrm{mol} / \mathrm{l})\end{array}$ & 8 & 146 & 142 & 18 \\
\hline
\end{tabular}

LTx, liver transplantation; ERCP, endoscopic retrograde cholangiopancreatography; PTCD, percutaneous transhepatic cholangio drainage.

The comparison of HEF between the groups showed significantly lower HEF values in the CSA group compared to the TAC group. In addition, none of the CSA patients had HEF of $100 \%$, with the range being $11 \%$ to $90 \%$, while in the TAC group, six patients (40\%) acquired $100 \%$ of HEF (Tables 2 and 3).

In view of biochemical parameters, at 3-month followup, there was no significant difference of ALAT, ASAT, ALP, and GT between the two groups except bilirubin in the TAC group that was significantly lower than in the CSA group, although both were within normal range (Table 2). This difference may to some extent explain the difference in HEF between the two groups. However, at the 1-year follow-up, there was no significant difference in liver function tests, including bilirubin and renal function tests, between the two groups (Table 3). Moreover, the results of three patients converted from CSA to TAC (Table 4) showed that HEF value increased without any substantial difference of bilirubin in two cases (cases

Table 6 Results of pathological parameters with CSA and TAC at 1-year control

\begin{tabular}{|c|c|c|c|}
\hline & $\begin{array}{l}\text { CSA } \\
(n=21)\end{array}$ & $\begin{array}{l}\text { TAC } \\
(n=14)\end{array}$ & $p$ value \\
\hline \multicolumn{4}{|l|}{ Inflammation } \\
\hline Low grade (0: none/1: light) & $16(2 / 14)$ & $4(1 / 5)$ & 0.005 \\
\hline High grade (2: moderate/3: severe) & $5(6 / 0)$ & $10(8 / 2)$ & \\
\hline \multicolumn{4}{|l|}{ Fibrosis } \\
\hline Low grade (0: none/1: light) & $12(2 / 10)$ & $6(2 / 4)$ & 0.40 \\
\hline High grade (2: moderate/3: severe) & $9(7 / 2)$ & $8(4 / 4)$ & \\
\hline \multicolumn{4}{|l|}{ Steatosis } \\
\hline Low grade (0: none/1: light) & $13(2 / 11)$ & $11(5 / 6)$ & 0.30 \\
\hline High grade (2: moderate/3: severe) & $8(5 / 3)$ & $3(2 / 1)$ & \\
\hline \multicolumn{4}{|l|}{ Recurrence of hepatitis C } \\
\hline Presence/absence & $12 / 9$ & $7 / 7$ & 0.68 \\
\hline
\end{tabular}

Three patients who converted CSA to TAC were not included in this analysis.
1 and 2) and in spite of a drastically increased bilirubin in one case (case 3). The patients who developed postoperative bile duct complication in the CSA group remained with low HEF value in spite of a normalized bilirubin level after treatment.

Although a 'cholestatic' effect of CSA, in contrast to TAC, as indicated by a significantly higher level of serum bilirubin at 3 months post-operatively should be considered, we interpret these overall data, supported by the animal experimental study, as CSA causing an incorrect diagnosis of hepatic dysfunction with hepatobiliary scintigraphy through CSA interference not seen for TAC.

The evaluation of liver biopsy showed that the degree of inflammation was higher in the TAC group than in the CSA group. There was no difference in other histological parameters; fibrosis, steatosis, and incidence of hepatitis $\mathrm{C}$ recurrence. In spite of a higher degree of inflammation in the TAC-treated patients, the HEF values were significantly better than in the CSA group. The reason for the higher degree of inflammation in the TAC group is not clear. Moreover, the CSA-treated patients with normal liver function tests and normal histology presented with HEF values that only ranged from $17 \%$ to $79 \%$.

Adenosine triphosphate (ATP)-binding cassette (ABC) subfamilies are bile canalicular transporters. ABC subfamily $\mathrm{C}$ member $2(A b c c 2)$ mediates the secretion of amphiphilic glutathione, glucuronide, and sulfate conjugates into bile. Excretion of ${ }^{99 \mathrm{~m}} \mathrm{Tc}$-mebrofenin from hepatocytes is mainly dependent on $A b c c 2$. CSA is known to be associated with the regulation of $A b c c 2$-dependent canalicular transport of bile salts and drugs [17]. Thus, the administration of CSA can inhibit ${ }^{99 \mathrm{~m}} \mathrm{Tc}$-mebrofenin excretion. An alternative mechanism is that low ${ }^{99 \mathrm{~m}} \mathrm{Tc}$ mebrofenin excretion is due to an elevated serum bilirubin value [14]. If so, this could partly explain the HEF difference at 3 months but not at 1 year after LTx. Inflammation of hepatocytes normally inhibits the ${ }^{99 \mathrm{~m}} \mathrm{Tc}-$ mebrofenin excretion [19]. In our groups, this should 
have had a negative effect on TAC-treated patients. Presumably, such a possible effect was less important than the negative effect on HEF by CSA.

To our knowledge, this study is the only investigation in which a correlation between scintigraphy and several clinical liver transplantation parameters, including liver biopsy, that has been performed.

\section{Conclusions}

Our finding has significant clinical implications as it indicates that the assessment of the liver graft function may be misleading, due to low HEF values in CSAtreated patients with otherwise good liver function. In conclusion, hepatobiliary scintigraphy in patients under CSA immunosuppression may show inadequately low HEF values.

\section{Abbreviations}

ALAT: alanine aminotransferase; ALP: alkaline phosphatase; ASAT: aspartate aminotransferase; AZA: azathioprine; CIT: cold ischemia time; CSA: cyclosporin A; LTX: liver transplantation; HCV: hepatitis C virus; HEF: hepatic extraction fraction; GT: gamma-glutamyl transpeptidase; TAC: tacrolimus; SD: standard deviation.

\section{Competing interests}

The authors declare that they have no competing interests.

\section{Authors' contributions}

AK performed the design of the study, data collection, data analysis, and writing the manuscript. SY participated in the data collection, analysis, and writing of the manuscript. GS RA and BGE provided additional help with data collection, editing, and revision of the manuscript. AW performed pathological analysis of the patient groups in this study. All authors read and approved the final manuscript.

\section{Acknowledgements}

Financial support was provided through the regional agreement on medical training and clinical research (ALF) between the Stockholm County Council and Karolinska Institutet.

\section{Author details}

'Division of Transplantation Surgery and CLINTEC, Karolinska University Hospital, Huddinge, and Karolinska Institutet, Stockholm, Sweden. ${ }^{2}$ Clinical Pathology/Cytology and CLINTEC, Karolinska University Hospital, Huddinge and Karolinska Institutet, Stockholm, Sweden. ${ }^{3}$ Division of Radiology and CLINTEC, Karolinska University Hospital, Huddinge and Karolinska Institutet, Stockholm, Sweden.

Received: 16 September 2014 Accepted: 28 November 2014 Published online: 17 December 2014

\section{References}

1. Groth CG: Forty years of liver transplantation: personal recollections Transplant Proc 2008, 40:1127-1129.

2. Wright TL, Donegan E, Hsu HH, Ferrell L, Lake JR, Kim M, Combs C, Fennessy S, Roberts JP, Ascher NL: Recurrent and acquired hepatitis c viral infection in liver transplant recipients. Gastroenterol 1992, 103:317-322.

3. Gjertsen H, Weiland O, Oksanen A, Söderdahl G, Broomé U, Ericzon BG: Liver transplantation for HCV cirrhosis at Karolinska University Hospital Huddinge, Stockholm. Transplant Proc 2006, 38:2675-2676.

4. Konig V, Bauditz J, Lobeck H, Lüsebrink R, Neuhaus P, Blumhardt G, Bechstein WO, Neuhaus R, Steffen R, Hopf U: Hepatitis c virus reinfection in allografts after orthotopic liver transplantation. Hepatology 1992, 16:1137-1143.

5. Gane EJ, Portmann BC, Naoumov NV, Smith HM, Underhill JA, Donaldson PT, Maertens G, Williams R: Long-term outcome of hepatitis c infection after liver transplantation. N Engl J Med 1996, 334:815-820.
6. Ascher NL, Lake JR, Emond J, Roberts J: Liver transplantation for hepatitis c virus-related cirrhosis. Hepatology 1994, 20:24S-27S.

7. Shah G, Demetris AJ, Gavaler JS, Lewis JH, Todo S, Starzl TE, Van Thiel DH: Incidence, prevalence, and clinical course of hepatitis c following liver transplantation. Gastroentero/ 1992, 103:323-329.

8. Kaibori M, Ha-Kawa SK, Kamiyama Y: Usefulness of tc-99 m GSA liver scintigraphy for the assessment of recurrent hepatitis c after living-donor liver transplantation: a case report. Transplant Proc 2008, 40:2837-2839.

9. Brunot B, Petras S, Germain P, Vinee P, Constantinesco A: Biopsy and quantitative hepatobiliary scintigraphy in the evaluation of liver transplantation. J Nucl Med 1994, 35:1321-1327.

10. de Graaf W, van Lienden KP, van Gulik TM, Bennink RJ: (99m)tc-mebrofenin hepatobiliary scintigraphy with spect for the assessment of hepatic function and liver functional volume before partial hepatectomy. J Nucl Med 2010, 51:229-236.

11. de Graaf W, Bennink RJ, Vetelainen R, van Gulik TM: Nuclear imaging techniques for the assessment of hepatic function in liver surgery and transplantation. J Nucl Med 2010, 51:742-752.

12. Mochizuki T, Tauxe WN, Dobkin J, Shah AN, Shanker R, Todo S, Starzl TE: Detection of complications after liver transplantation by technetium99 m mebrofenin hepatobiliary scintigraphy. Ann Nucl Med 1991, 5:103-107.

13. Ericzon BG, Eliasson GJ, Barkholt L, Cederlund T, Lewander R, Groth CG: Early detection of malfunctioning liver grafts with liver-to-spleen res scintigram ratio. Transplant Proc 1989, 21:2297-2298.

14. Kansoul HA, Axelsson R, Yamamoto S, Savicheva I, Aspelin P, Ericzon BG Gjertsen H: Parameters obtained by hepatobiliary scintigraphy have significant correlation with biochemical factors early after liver transplantation. Acta Radiol 2007, 48:597-604.

15. Daniel GB, Bahr A, Dykes JA, DeNovo R, Young K, Smith GT: Hepatic extraction efficiency and excretion rate of technetium-99 m-mebrofenin in dogs. J Nucl Med 1996, 37:1846-1849.

16. Brown PH, Juni JE, Lieberman DA, Krishnamurthy GT: Hepatocyte versus biliary disease: a distinction by deconvolutional analysis of technetium99 m IDA time-activity curves. J Nucl Med 1988, 29:623-630.

17. Bhargava KK, Joseph B, Ananthanarayanan M, Balasubramaniyan N, Tronco GG, Palestro CJ, Gupta S: Adenosine triphosphate-binding cassette subfamily c member 2 is the major transporter of the hepatobiliary imaging agent (99 m)tc-mebrofenin. J Nucl Med 2009, 50:1140-1146.

18. Nag A, Robotham JM, Tang H: Suppression of viral rna binding and the assembly of infectious hepatitis c virus particles in vitro by cyclophilin inhibitors. J Virol 2012, 86:12616-12624.

19. Joseph B, Bhargava KK, Tronco GG, Kumaran V, Palestro CJ, Gupta S: Regulation of hepatobiliary transport activity and noninvasive identification of cytokine-dependent liver inflammation. J NuCl Med 2005, 46:146-152.

doi:10.1186/s13550-014-0073-z

Cite this article as: Kaxiras et al:: Cyclosporin A, but not tacrolimus, negatively affects the hepatic extraction fraction of hepatobiliary scintigraphy in liver transplant recipients. EJNMMI Research 2014 4:73.

\section{Submit your manuscript to a SpringerOpen ${ }^{\odot}$ journal and benefit from:}

- Convenient online submission

- Rigorous peer review

- Immediate publication on acceptance

- Open access: articles freely available online

- High visibility within the field

- Retaining the copyright to your article

Submit your next manuscript at springeropen.com 